\title{
大規模最終処分場安定化モニタリングにおける NDVI の利用可能性に関する検討
}

\author{
小宮 哲平 ${ }^{1}$ - 石崎 俊夫 $^{2} \cdot$ 中山 裕文 $^{3} \cdot$ 島岡 隆行 ${ }^{4}$ \\ ${ }^{1}$ 学生会員 九州大学大学院 工学府都市環境システム工学専攻（†812-8581 福岡市東区箱崎 6-10-1） \\ E-mai1: komiya@ies. kyushu-u. ac.jp \\ 2 正会員 山口県（†753-8501 山口県山口市滝町 1 番 1 号） \\ ${ }^{3}$ 正会員 九州大学大学院助手 工学研究院環境都市部門 ( \\ E-mai1: nakayama@ies. kyushu-u. ac. jp \\ ${ }^{4}$ 正会員 九州大学大学院教授 工学研究院環境都市部門（同上） \\ E-mail: shimaoka@ies. kyushu-u. ac. jp
}

\begin{abstract}
本研究では, 衛星リモートセンシングを用いて広大な面積を有する大規模最終処分場の安定化状況をモ ニタリングする手法について検討した. 上海市廃棄物老港処置場を対象とし, 現地調査で得られた廃棄物 層ガス組成と衛星リモートセンシングで得られた NDVI (Normalized Difference Vegetation Index: 正 規化差分植生指標）との関連性について検討した. 両者の間には一定の相関が見られ，NDVI を使用する ことで廃棄物層のガス組成を推定できることを示した。 また, 多時期の衛星画像から得られた NDVI の時 期変動パターンを用いることで, 処分場内の植生を分類し, 植生遷移状況の推定及び植生遷移段階が遅延 していると考えられる箇所を検出する手法について検討した.
\end{abstract}

Key Words: large-scale landfill site, stabilization, satellite remote sensing, NDVI, landfill gas

\section{1. はじめに}

近年急成長を遂げたアジア地域の大都市では様々な環 境問題が起きているが, とりわけ増大する廃棄物への対 応に迫られている. 中国の都市部における生活ごみの収 集量”は，1985 年に約 4300 万トンであったが，2004 年 には約 15500 万トンとなり約 4 倍に増加している. この ような大量の廃衰物に対し, 多くの都市では焼却等の中 間処理を経由せずに直接埋立処分を行っているため, 衛 生的に廃衰物を処分するための最終処分場の確保が重要 となっている.このため, いくつかの大都市では数百 ha もの広大な面積を有する大規模な最終処分場が建設， 整備されている. 例えば，上海市廃棄物老港処分場 (343ha), 福州市紅庙岭衛生埋立場 (333ha) は中国最大級 の最終処分場であり，他に 100ha を超える最終処分場は 数多く存在する.

ここで，廃㲤物処分場においては，土砂の埋立地とは 異なり, 埋立てられた廃裹物の微生物分解等により, 浸
出水やガスの発生, 地盤沈下等が生じ, かつこれらが長 期間に渡って続く. 特に, 埋立廃棄物の内容が, わが国 のような焼却灰主体ではなく, 未分解の有機物主体であ る場合, こうした現象は顕著となる. このため, 処分場 のモニタリングを行い, 廃棄物の安定化度を把握・評価 することが求められるが，対象が大規模である場合，モ ニタリングに多大な時間, 労力, コストを要し, 定期的 な調査を行うことは困難を極める. また，現行の調査は モニタリング井戸やガス抜き管等の処分場内のある特定 の観測点においてなされるが，廃棄物処分場は場所によ って状況が大きく異なるため, 現行の手法では処分場全 体の安定化の状況を把握できないという課題が残されて いる.

以上のような課題に対し，著者らは，埋立地表層の植 生の状況を利用して埋立層内部の廃棄物の安定化度を評 価する手法について検討してきた ${ }^{2)}{ }^{2)}{ }^{4)}$ ）．埋立完了後の 区画において，覆士の表層が植物に覆われた被植地と， 覆土表層に植物が生えていない裸地において，廃棄物層 
内のガス組成を測定した結果, 裸地において $\mathrm{CH}_{4} や \mathrm{CO}_{2}$ 等の埋立ガスの割合が高いことが分かった. また, 埋立 廃衰物をサンプリングして分析した結果, 廃棄物中の有 機物量の指標である, 強熱減量, $\mathrm{C} / \mathrm{N}$ 比, 溶出液の有機 酸濃度および全有機炭素濃度はいずれも裸地のほうが高 かった. つまり, 廃棄物の安定化の度合いと植生の間に は関連性があることが示された。ここで, 埋立地におけ る覆土表層の植物活性度や植生の分布状況については, 衛星画像から算出される NDVI (Normalized Difference Vegetation Index : 正規化差分植生指標）を用いること で面的に把握できるため, 植生情報を利用して間接的に 埋立地の安定化度を把握することが可能と考えられた。

しかしながら,これまでの研究においては, 廃棄物処分 場において現地調查を実施した時期の衛星画像がなく, 上記手法に基づく埋立ガスの推定や推定結果の精度検証 を行うことができなかった.

そこで, 本研究では, 廃棄物処分場における現地調査 の実施時期に合わせて衛星画像の撮影を依頼し, 得られ た画像と現地調查結果に基づき, NDVI による埋立地の 安定化度推定の精度について検証した. さらに, 推定精 度向上を目的とし, 多時期の衛星画像を用いた植物種の 識別法の適用について検討した。

\section{2. 分析方法と研究対象}

\section{（1）分析方法}

本研究で実施した分析の流れについて説明する. ま ず, 対象とする最終処分場において現地調查を行い, 埋 立てられた廃棄物の安定化度に関する調査を実施した。 廃棄物埋立地の安定化度を把握するための指標 ${ }^{5)}$ とし ては, (1)埋立廃棄物の性状, (2浸出水, (3)埋立ガス, (4) 廃棄物層内の温度, (5)埋立地表層の状況（沈下量, 植生 等）がある. このうち, 埋立廃棄物の性状が, 直接的に 安定化度を把握できる指標であるが, 埋め立てられた廃 菓物は不均質であるので, 埋立地の状況を代表する指標 を採取するのが困難であることや，埋立方法等によって は調査そのものが困難であること等の理由から, 多くの 場合, 間接的な指標である(2)〜(5)の指標が用いられてい る ${ }^{6}$. 本研究の目的の一つは, NDVI による安定化度評価 手法の精度を検証することであり，そのためにはなるべ く多数の地点において安定化指標に関するデータを取得 する必要があった. そこで, 上述の安定化指標のうち, 埋立廃棄物の微生物分解に伴い発生する「埋立ガス」に 着目し，比較的短時間に多数の測定が実施可能な「廃棄 物層内の埋立ガス組成」を安定化指標として採用した. また，埋立ガスの測定と併せて，コドラートを用いた植 生調查を実施した.

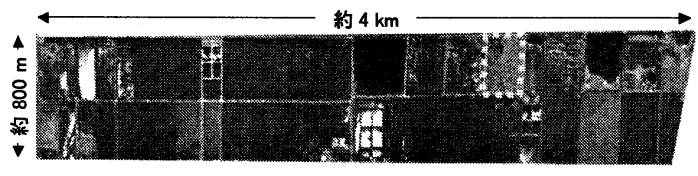

※ 破線の範囲は現地調查を実施した埋立区画

図-1 老港処分場の全景写真 (Quickbird 衛星画像, 2002 年 7 月 11 日撮影, トゥルーカラー表示)

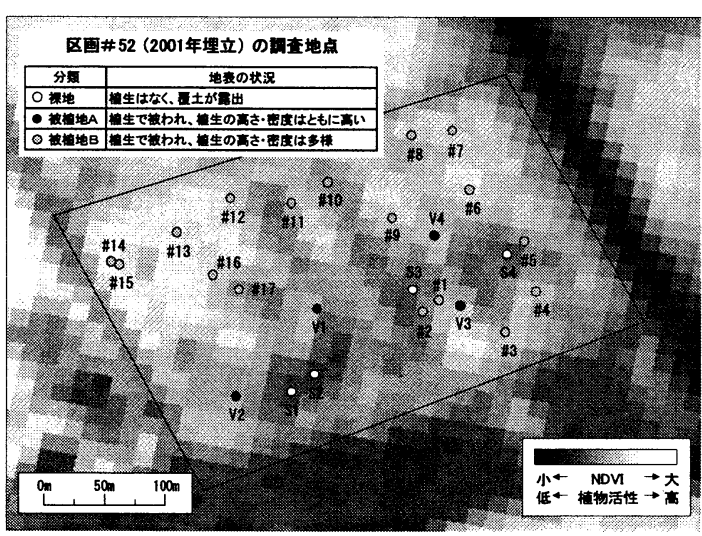

図-2 現地調査地点（背景は 2005 年 5 月の NDVI）

一方, 現地調查と同時期に撮影された衛星画像を用い て, 植生の分布状況を NDVI により把握し，現地におい て得られた埋立ガスの測定データとの関連性について分 析した. 本研究で使用した衛星画像は，(1)NVI を算出 するための観測波長帯 (可視光（赤）の波長域および近 赤外波長域) を有すること，(2)埋立地における NDVI の 分布をある程度詳細に把握可能な空間分解能を有するこ と，(3)時期を特定して画像撮影を依頼できること，(4)高 頻度で定期的な観測が可能であること等の理由により， Terra/ASTER-VNIR を採用することとした.

\section{(2) 研究対象}

対象とした最終処分場は，中国上海市の廃棄物老港 処置場（以下，老港処分場）である（図-1）。老港処分 場は，上海市南東部の長江河口域の湿地帯に位置してお り，1989 年建設された. 敷地面積は約 343ha，埋立面積 は約 300 ha と広大な面積を有する中国最大規模の最終 処分場である. この処分場では，上海市中心部で収集さ れた都市ごみが埋立てられており, 日処理量は約 $4900 t$, ごみの組成は, 有機物が約 $45 \%$, 無機物が約 $45 \%$, 不燃物が約 $10 \%$ である. 埋立方式は, 嫌気性埋立で, 1 つの埋立区画（搬入路で囲まれている範囲，約 5 〜 10 ha ）の埋立高さが $4 \sim 8 \mathrm{~m}$ になるまで埋立てられ， その後 $20 \sim 60 \mathrm{~cm}$ 程度の最終覆土が施されている. 1 区画の埋立てが完了するまでの期間は約 1 年である. 


\section{3. 現地での植生調査と廃棄物層ガス組成調査}

\section{(1) 調査地点}

2005 年 9 月 13 日，14 日に，老港処分場の埋立終了区 画において地表植生の調查と廃棄物層ガス組成調查を行 った. 図-2 に調查地点を示す. 図中の線で囲まれた四 角形の範囲は調查を行った埋立区画（約 9.3 ha, 図-1 では点線の範囲）である.ここでは 2001 年に埋立が行 われ，埋立終了後約 4 年が経過していた. 図-2 の背景 には，参考として，2005 年 5 月の NDVI を示している.

区画内を踏査し, 調查地点を選定した. ここでは, 植生がなく覆土が露出している箇所（以下，裸地）を 4 地点, 植生の密度, 高さがともに高い箇所（以下, 被植 地A）を 4 地点選定した. さらに, 植生の密度, 植生高 さが被植地 A よりも低く，ばらつきがある場所（以下， 被植地 $\mathrm{B}$ )を 17 地点選定した. なお, 各調査地点及び 調査区画の四隅にて，GPS による緯度・経度の測定を行 い, 衛星画像と正確に対応できるよう調查地点の位置を 把握した.

\section{（2）植生調查}

各調査地点において調査方形区（コドラート）を設 け，コドラート内において植生調査 ${ }^{7,8)}$ を実施した。 コ ドラートの大きさは, 調査地点に成立している群落の植 生高を参考に，おおむね $5 \mathrm{~m} \times 5 \mathrm{~m}$ に設定した. その後, 海抜高さや地形等のコドラートの立地条件について記録 し, 設定したコドラートにおいて植生の階層構造を把握 した. なお, 埋立区画内に樹木は無く, 調査対象は草本 層のみであった. 次いで, 出現種, 植被率, 植生高を目 測により観察，記録した.

\section{（3）廃棄物層ガス組成の測定}

植生調査を実施したコドラート内において，位置が 分散した 3 地点を選定し, 廃棄物層内のガス組成を測定 した. 測定方法を図-3に示す. まず，ボーリングバー で約 $80 \mathrm{~cm}$ の深さまで穿孔し，その孔内にガス採取管を 挿入した. 次に，孔内及び採取管内に外気が入らないよ う密閉した状態で数分間静置した. その後, コックを開 き, 原位置ガス調査器（GA2000, Geotechnial Instruments 社）を用いて $\mathrm{CH}_{4}, \mathrm{CO}_{2}, \mathrm{O}_{2}, \mathrm{CO}$ 及び $\mathrm{H}_{2} \mathrm{~S}$ のガ ス組成割合を測定した.

\section{（4）植生調査・廃棄物層ガス組成調查結果}

表-1 に現地において実施した植生調查および埋立ガ ス組成調査の結果を示す. 裸地における廃棄物層のガス 組成は, $\mathrm{CH}_{4}$ が 53〜 58\%， C0 2 が 31〜39\%を占めている. このことから, 裸地においては微生物による廃裹物の分 解が活発であり，また $\mathrm{CH}_{4}$ の割合が高いことから嫌気的

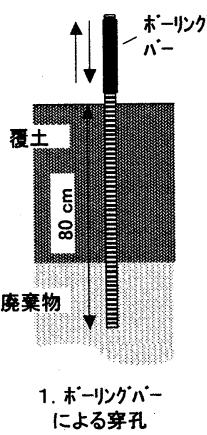

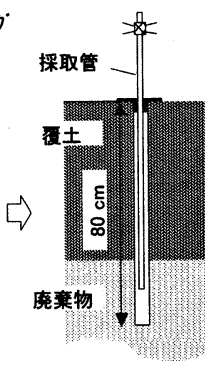

2. 採取管を插入し 密閉状態で静置

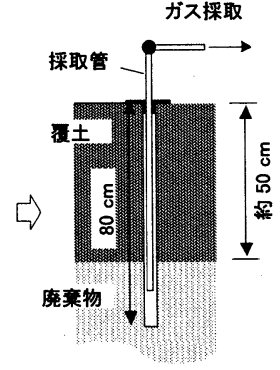

3. コックを開き ガス組成を測定
図-3 廃棄物層ガス組成の測定方法

表-1 植生および廃棄物層ガス組成の調査結果

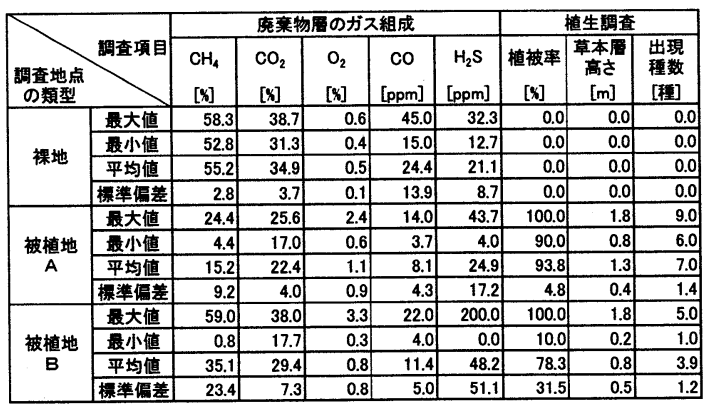

な状況にあることがわかる，言い換えれば，ガス調査の 結果からみると, 裸地においては廃棄物の安定化が進ん でいないといえる.一方，植被率が $90 \sim 100 \%$ と植生の 密度が高い被植地 $\mathrm{A}$ においては, 廃棄物層ガス組成のう ち, $\mathrm{CH}_{4}$ の割合が 4〜24\%，CO て低く, 裸地と比較して廃棄物は安定な状態にあること がわかる．被植地 B では，調査地点により廃棄物層ガス 組成のばらつきが大きいが，平均值でみると， $\mathrm{CH}_{4}, \mathrm{CO}_{2}$

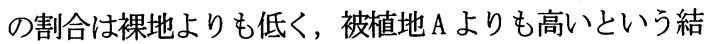
果が得られた. なお，草本層高さは被植地 $\mathrm{A}$ において $0.8 \sim 1.8 \mathrm{~m}$ ，被植地 B において $0.2 \sim 1.8 \mathrm{~m}$ ，出現種数は, 被植地 $\mathrm{A}$ において $6 \sim 9$ 種, 被植地 $\mathrm{B}$ において 1 5 種で あった。

表-2 は, 調查地点における群落の種構成を示したも のである. 表中の数值は被度および群度であり,「被 度・群度」の順で表記した. また, 数值が太字で表記さ れている種は, その地点における優占種を意味する. こ の表から, 調査を行った区画では, ヨシ群落, アキノエ ノコログサ群落, カナムグラ群落, イネ科の不明な種の 群落が多いことがわかる. また，4 地点においてメタン ガスの指標植物として知られているセイタカアワダチソ ウが確認された ${ }^{9)}$.ヨシ群落が多い理由としては, この 処分場では建設時に湿地帯を掘り返した土を覆土として 使用しており，ヨシの根茎が覆士に含まれていたためと 考えられた. 
表-2 調査地点における群落の種構成

\begin{tabular}{|c|c|c|c|c|c|c|c|c|c|c|c|c|c|c|c|c|c|c|c|}
\hline \multirow{2}{*}{\multicolumn{2}{|c|}{ 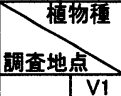 }} & $\begin{array}{l}\text { Pキ/IJ } \\
\text { Jםグサ }\end{array}$ & $\begin{array}{l}\text { 柿丰 } \\
\eta\end{array}$ & $\begin{array}{l}\text { Exムか } \\
\text { ヨモギ }\end{array}$ & 归 & 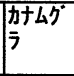 & $\begin{array}{l}\text { 不明(1 } \\
\text { 祮科) }\end{array}$ & 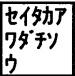 & カガ任 & 夕仅士゙I & $\begin{array}{l}\text { 不明(加 } \\
\text { †"将 } \\
\text { 科) }\end{array}$ & アサガオ & $\begin{array}{l}\text { PレチJ } \\
\text { ギク }\end{array}$ & \begin{tabular}{|l|} 
ツ/クサネネ \\
$厶$
\end{tabular} & 仅 I & $\begin{array}{l}\text { 标 } \\
x^{*} \neq\end{array}$ & $\begin{array}{l}\text { スズメ } \\
\text { エンドウ }\end{array}$ & シ呅 & アアカザ \\
\hline & & 5.5 & $1 \cdot 1$ & 1.1 & + & + & & + & & & & & & & & & & & \\
\hline \multirow{3}{*}{$\begin{array}{c}\text { 被植地 } \\
\text { A }\end{array}$} & V2 & 3.3 & + & 1.1 & $4: 4$ & $1 \cdot 2$ & & $2 \cdot 2$ & & & & & & + & & & & & \\
\hline & V3 & $3 \cdot 3$ & 1.1 & $2 \cdot 2$ & + & 3.3 & & $1 \cdot 1$ & +.2 & & & & & & & + & & + & \\
\hline & $\mathrm{V4}$ & $1 \cdot 1$ & + & 3.3 & + & $1 \cdot 2$ & & & 3.4 & & & & & & & & & & \\
\hline \multirow{16}{*}{$\begin{array}{c}\text { 被植地 } \\
\text { B }\end{array}$} & $\# 02$ & + & 1.1 & $2 \cdot 2$ & $4 \cdot 4$ & & & & & & & & & & & & + & & \\
\hline & $\# 03$ & + & + & & & & & & & & $2 \cdot 2$ & & & & & & & & \\
\hline & $\# 04$ & $1 \cdot 2$ & + & + & & & 5.5 & & & & & & & + & & & & & \\
\hline & $\# 05$ & $2 \cdot 2$ & $2 \cdot 2$ & $3 \cdot 3$ & & & & & $3 \cdot 3$ & & & & & & & & & & \\
\hline & $\# 06$ & + & $2 \cdot 2$ & & $4 \cdot 4$ & & & & 1.2 & & & & + & & & & & & \\
\hline & $\# 07$ & & 1.1 & & 5.5 & & & & & & & & + & & & & & & \\
\hline & $\# 08$ & & & & & & & & & & & 5.5 & & & & & & & \\
\hline & $\# 09$ & & + & & + & & $5 \cdot 5$ & & & & & & & & & & & & \\
\hline & $\# 10$ & & + & & 5.5 & & & & & & & & & & & + & & & \\
\hline & $\# 11$ & + & & & & & 4.4 & & & & & + & 1.1 & $1 \cdot 1$ & & & & & \\
\hline & \#12 & & $4 \cdot 4$ & & + & & $3 \cdot 3$ & & & & & & & & & & & & \\
\hline & $\# 13$ & 2.2 & & & 1.1 & & & & & + & & & + & & & & & & \\
\hline & $\# 14$ & +-2 & & $2 \cdot 2$ & & 3.4 & + & 3.3 & & & & & & & & & & & \\
\hline & $\# 15$ & + & & & & 3.4 & & $3 \cdot 3$ & & & & & + & & & & & & \\
\hline & $\# 16$ & 5.5 & $1 \cdot 1$ & & + & & $+\cdot 2$ & + & & & & & & & & & & & \\
\hline & \#17 & & & & & & & & & 1.2 & & & & & $+\cdot 2$ & & & & + \\
\hline
\end{tabular}

注）被度・群度の表記は,「被度・群度」の順で表記し, 被度が「十」で群度が「1」の場合は, 群度の「1」を省略して 「十」と表記した. また, 被度・群度が太字で表記されている種は, その区画における優占種である.

表-3＼cjkstart使用した衛星画像のセンサ及び観測日

\begin{tabular}{|c|c|c|c|c|c|c|}
\hline \multicolumn{3}{|c|}{ 衛星センサの諸元 } & \multirow{2}{*}{ 用途 } & \multicolumn{3}{|c|}{ 観測日 } \\
\hline 衛星／ゼサ名 & 䚇測波長带 & 空間 & & 年 & 月 & 日 \\
\hline \multirow{7}{*}{$\begin{array}{c}\text { Terra / } \\
\text { ASTER-VNIR }\end{array}$} & \multirow{7}{*}{$\begin{array}{c}\text { バンド1: } \\
0.52-0.60 \mu \mathrm{m} \\
\text { バンド2: } \\
0.63-0.69 \mu \mathrm{m} \\
\text { バンド3: } \\
0.78-0.86 \mu \mathrm{m}\end{array}$} & \multirow{7}{*}{$15 \mathrm{~m}$} & \multirow{2}{*}{$\begin{array}{c}\text { 廃棄物層 } \\
\text { ガ組成と } \\
\text { 相関分析 } \\
\end{array}$} & 2005 & 5 & \\
\hline & & & & $"$ & 10 & 11 \\
\hline & & & \multirow{5}{*}{$\begin{array}{c}\text { 植生状況の } \\
\text { 分類 }\end{array}$} & 2002 & 4 & \\
\hline & & & & $\prime \prime$ & 5 & 28 \\
\hline & & & & $" \prime$ & 8 & 23 \\
\hline & & & & $\prime \prime$ & 10 & 26 \\
\hline & & & & $" \prime$ & 11 & 11 \\
\hline
\end{tabular}

\section{NDVI を用いた廃棄物層ガス組成の推定手法の 検討}

次に，現地調查実施日に近い時期に撮影された衛星 画像を用いて NDVI を算出し, 現地で得られた廃棄物層 ガス組成との相関について分析しここれにより NDVI を 用いた廃棄物層ガス組成の推定手法の精度について検討 した.

\section{（1）使用した衛星画像}

本研究では衛星光学センサ Terra/ASTER-VNIR により観 測された老港処分場の衛星画像（以下, ASTER 画像) を 使用した. 表-3 にセンサの諸元及び使用した画像の観 測日を示す. ASTER VNIR センサは可視・近赤外域に 3 つ の観測波長帯 (バンド) を持ち, $15 \mathrm{~m}$ の空間分解能を有 する.ここで使用した画像の観測日は，2005 年の 5 月 11 日及び 10 月 11 日である.

ASTER 画像は処理レベル L1B のものを使用し，画像解 析の前処理として幾何補正を行った. また，各画像には

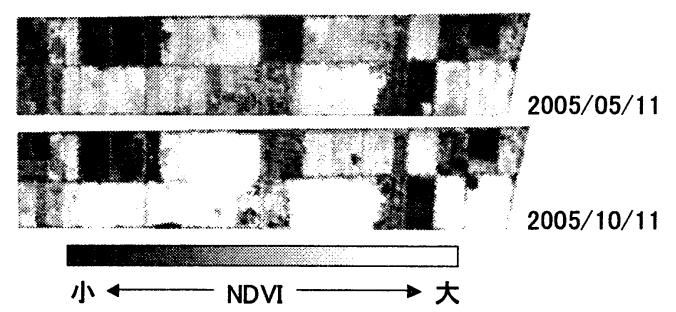

図-4 老港処分場の NDVI 算出画像

表-4 NDVI を用いた変数と廃棄物層ガス組成の相関係数

\begin{tabular}{|l|r|r|r|r|r|}
\hline & \multicolumn{1}{|c|}{$\mathrm{CH}_{4}$} & \multicolumn{1}{c|}{$\mathrm{CO}_{2}$} & \multicolumn{1}{c|}{$\mathrm{O}_{2}$} & \multicolumn{1}{c|}{$\mathrm{CO}$} & \multicolumn{1}{c|}{$\mathrm{H}_{2} \mathrm{~S}$} \\
\hline $\mathrm{NDVI}$ (5月) & -0.39 & -0.35 & 0.24 & -0.62 & 0.19 \\
\hline $\mathrm{NDVI}$ (10月) & -0.51 & -0.50 & 0.40 & -0.58 & 0.20 \\
\hline $\mathrm{NDVI}$ 平均 & -0.44 & -0.41 & 0.30 & -0.63 & 0.20 \\
\hline $\mathrm{NDVI}$ 差 & 0.21 & 0.16 & -0.06 & 0.53 & -0.15 \\
\hline $\mathrm{NDVI}$ 増加率 & 0.30 & 0.23 & -0.15 & 0.68 & -0.16 \\
\hline
\end{tabular}

大気補正処理を施し，各バンドの輝度值を反射率に変換 した. なお，これらの画像処理には ERDAS IMAGINE 8.6 を使用し，大気補正処理には ERDAS IMAGINE のオプショ ンツールである ATCOR 2.0 を使用した.

\section{（2）NDVI の算出}

NDVI は多バンド光学センサによる観測データから算 出される植生指標で, 地表植生の有無や活性度を評価す る指標として広く用いられている. NDVI の算定式 ${ }^{10}$ は 次のとおりである.

$$
N D V I=\frac{N I R-R}{N I R+R}
$$

ここで $N I R$ は近赤外バンドの反射率，Rは可視域赤バン ドの反射率である. これは, 植物の葉が近赤外域の電磁 
波を強く反射し，また葉に含まれるクロロフィルが可視 域赤色の電磁波を強く吸収する特性を利用したものであ る. ASTER 画像では, NIR にバンド $3, \mathrm{R}$ にバンド 2 の反 射率をそれぞれ代入することで, NDVI が算出される.

ASTER-VNIR 画像は 1 つの画素が 15m 四方であるため, 画素内に複数種類の植物が存在することもあり，この場 合 NDVI は画素内での面積占有率が高い植物の影響を強 く受けていることに留意する必要がある.

図-4に 2005 年の老港処分場の NDVI 画像を示す. 画像 において, 色が白いところほど NDVI が高く, 植生の活 性が高いことを意味する.これらの画像を見ると, 場所 によって NDVI が異なっていることや, 時期変化に伴う NDVI の増減傾向が場所によって異なっていることがわ かる.

\section{(3) NDVI と廃棄物層ガス組成との相関}

現地調查日に近い 2005 年 5 月及び 10 月の NDVI 算出 画像において, 調査地点の NDVI を抽出し, 現地で計測 した廃棄物層ガス組成と NDVI との関連性について検討 した.

表-4 は, 現地調査により得られた廃棄物層ガス組成 と, 衛星画像より得られた NDVI との単相関を見たもの である.ここでは， 5 月および 10 月の NDVI に加え，現 地調查日が 9 月であることから 5 月と 10 月の NDVI の平 均值, また植生の生長度合いを示す指標として 5 月と 10 月の NDVI の差および 5 月から 10 月にかけての NDVI の増加率ついても, 廃棄物層ガス組成との相関について 調べた. 相関分析の結果, 現地で測定した 5 種類のガス のうち, 3 種類 $\left(\mathrm{CH}_{4}, \mathrm{CO}_{2}\right.$ および $\left.\mathrm{O}_{2}\right)$ において 10 月の NDVI と最も高い相関を示寸結果となった. 残りの 2 種 類については, 00 は NDVI の増加率, $\mathrm{H}_{2} \mathrm{~S}$ は NDVI の平均 値に対して最も高い相関を示した.

図-5に 10 月の NDVI と廃菓物層ガス組成の関係を示 す. $\mathrm{CH}_{4}, \mathrm{CO}_{2}$ 及び $\infty$ の割合は, NDVI が大きくなるにつ れ减少傾向にあった. 一方, $\mathrm{O}_{2}$ 及び $\mathrm{H}_{2} \mathrm{~S}$ では増加傾向が 見られた. 相関係数を見ると， $\mathrm{CH}_{4}$ で-0.51，CO $\mathrm{CO}_{2}$ で-0.50， $\mathrm{O}_{2}$ で $0.40, \mathrm{CO}$ で-0. 58, $\mathrm{H}_{2} \mathrm{~S}$ で 0.20 であった.

\section{（4）廃棄物層ガス組成の面的分布状況の推定}

前項で言及した NDVI，と廃棄物層ガス組成との間の相 関関係を利用することで，NDI 算出画像から廃棄物層 ガス組成の面的分布状況を推定することが可能であると 考えられる. 次式は, 図-5 のデータから得られた, $\mathrm{NDVI}$ と $\mathrm{CH}_{4}$ ガス組成割合との間の線形関倸式である.

$$
Y_{\mathrm{CH}_{4}}=-227.9 \times \mathrm{NDVI}+173.8
$$

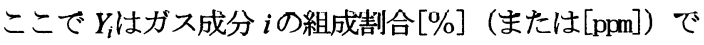
ある。この関係式を用い，NDVI 算出画像から廃棄物層
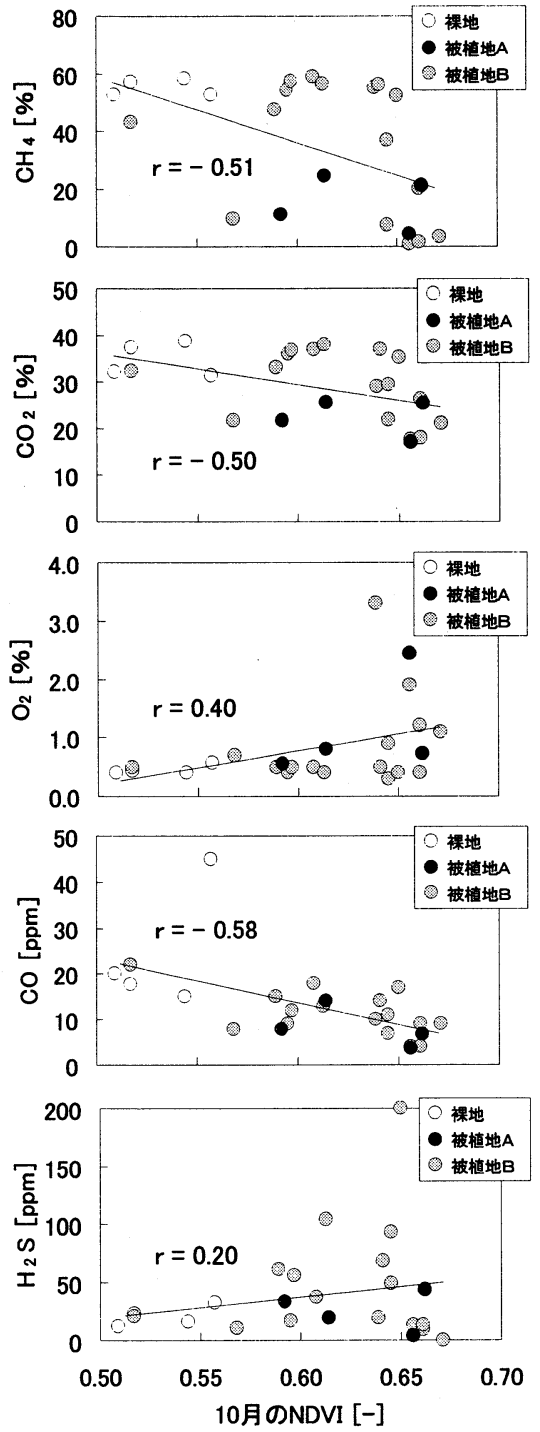

図-5 NDVI（10月）と廃棄物層ガス組成の相関

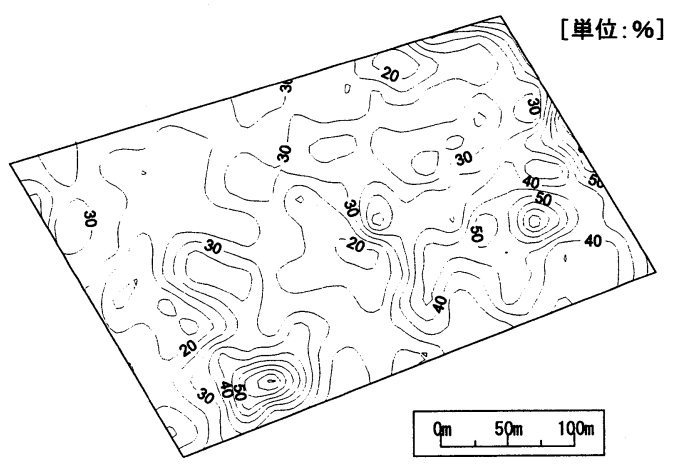

図-6 廃菓物層内の $\mathrm{CH}_{4}$ オ゙ス組成割合の面的分布推定結果 
内の $\mathrm{CH}_{4}$ ガス組成割合の面的分布状況を推定した結果を 図-6に示寸.

このように, NDVI との間の関係式を見出すことで, 廃棄物層内の状況を面的に推定することが可能である. 通常の調査では，図一 のような分布図を作成する場合， 区画内を格子状に区切り，格子の各接点において測定し たデータを等值線作成ソフトに入力する必要がある.こ のため，老港処分場のような大規模な最終処分場におい て廃棄物層ガス組成の分布状況を調査する場合, 多数の 地点においてガス測定を実施する必要がある. 本手法を 用いれば，NDVI と廃棄物層ガス組成との関係式を推定 できるだけのデータをそろえれば，比較的簡便に分布図 を作成することが可能である． また，このような分布 図は，人手では把握が困難な広範囲の状況を把握できる ため, 現地での詳細な調查を実施する際の調査地点の選 定ツールとしての活用も期待される.

\section{5. 推定精度改善のための検討}

次に, 上述した NDVI による廃棄物層内ガス組成の推 定手法の精度を改善するための方策について検討した。

\section{（1）草本層高さと廃棄物層ガス組成の関係}

現地で得た植生データのうち草本層高さに着目し, 草 本層高さと廃棄物層ガス組成の関係を図示したものを 図-7 に示す．草本層高さが高くなるにつれ， $\mathrm{CH}_{4} ， \mathrm{CO}_{2}$, $\mathrm{C}$ 及び $\mathrm{H}_{2} \mathrm{~S}$ の組成割合は減少し， $\mathrm{O}_{2}$ では増加傾向にあり， 草本層高さと廃棄物層ガス組成には相関関係がみられた.

そこで, NDVI に加えて草本層高さも説明変数とし， 各ガス成分の組成割合を被説明変数とした重回帰式（式 （3）を作成した.

$$
Y_{i}=a_{0}+a_{1} X_{1}+a_{2} X_{2}
$$

ここで $Y_{i}$ はガス成分 $i$ のガス組成割合[\%]（または [ppm]）， $X_{1}$ は 10 月の NDVI [-]， $X_{2}$ は草本層高さ $[\mathrm{m}]$ とし， $a_{0}, a_{1}, a_{2}$ は偏回帰係数である. 表-5 に偏回帰係数およ びガス組成割合の回帰值と実測值の重相関係数を示す. 説明変数が NDVI のみの場合（図-5） と比較すると， $\mathrm{CH}_{4}$, $\mathrm{CO}_{2}$ 及び $\mathrm{H}_{2} \mathrm{~S}$ の 3 成分において，相関の顕著な向上が見ら れた.

このように, 衛星から得られる NDVI と併せて, 草本 層高さに関する情報を用いることにより，廃棄物層ガス 組成の推定精度は向上するものと考えられた.

（2）NDVI の時期変動パターンによる植生状況の分類及び 植生遷移状況の把握 草本層高さは植物の種類によって異なることから，衛とを試みた。
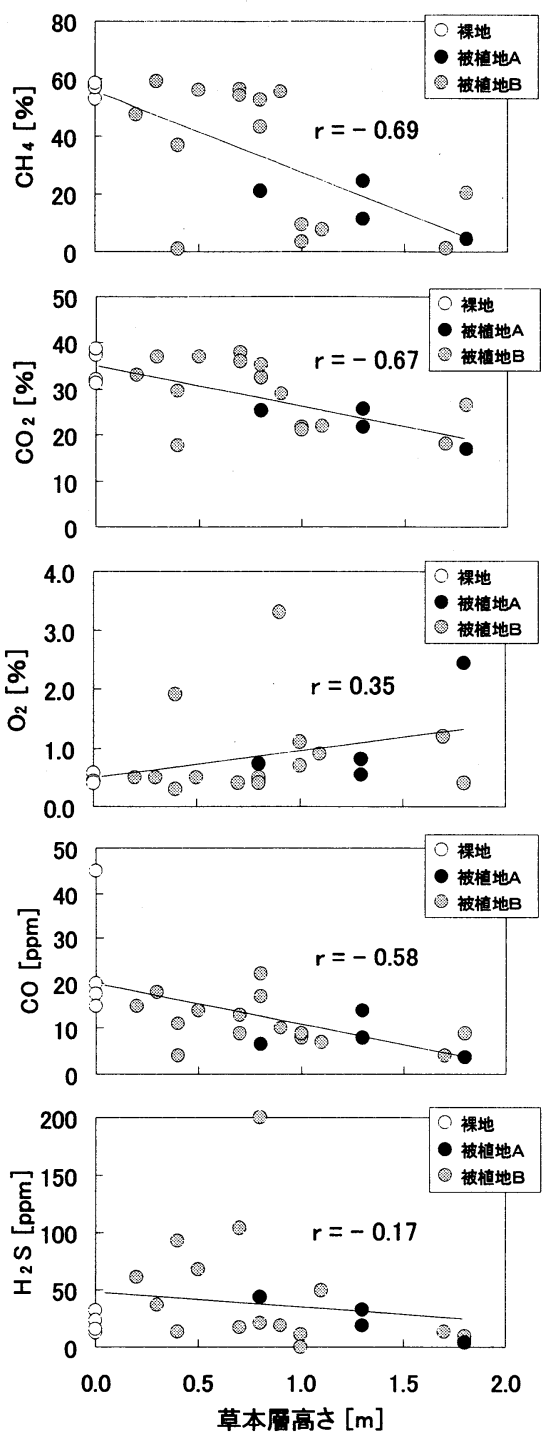

図-7 草本層高さと廃棄物層ガス組成との相関

表-5 重回㷌モデルの偏回帰係数と実測值との相関

\begin{tabular}{|c|c|c|c|r|}
\hline \multirow{2}{*}{} & \multicolumn{2}{|c|}{ 偏回带係数 } & $\begin{array}{c}* *: 1 \% \text { 有意 } \\
*: 5 \% \text { 有意 }\end{array}$ & \multirow{2}{*}{ 重相関 } \\
\cline { 2 - 4 } & $\mathrm{a}_{0}$ & \multicolumn{1}{|c|}{$\mathrm{a}_{1}$} & \multicolumn{1}{c|}{$\mathrm{a}_{2}$} & \\
\hline $\mathrm{CH}_{4}$ & 98.1 & -75.9 & $-23.3 * *$ & 0.70 \\
\hline $\mathrm{CO}_{2}$ & $48.5 * *$ & -23.1 & $-7.3 *$ & 0.68 \\
\hline $\mathrm{O}_{2}$ & -1.9 & 4.2 & 0.2 & 0.42 \\
\hline $\mathrm{CO}$ & $55 *$ & -61 & -5.7 & 0.65 \\
\hline $\mathrm{H}_{2} \mathrm{~S}$ & -170 & 385 & -33.7 & 0.40 \\
\hline \multicolumn{3}{|c|}{ ※データ数は調查地点数の25 } \\
\hline
\end{tabular}

星画像により植物の分類ができれば，それによって草本 層高さを推定できると考えられる．そこで，ここでは， 多時期の衛星画像を用いて処分場内の植生を分類するこ 
表一 は老港処分場での現地調查で確認された植物種 を例にとり，その生活型及び生育・成長期間 11),12)を示し たものである. 表一 を見ると, 植物の種類により生 育・成長期間が異なることが見て取れる. 植物の生育・ 成長または枯化に伴い NDVI が増減することを踏まえる と, NDVI の時期変動パターンを分析することで, 埋立 地表層の植物種の違いを識別できると考えられる ${ }^{13)}$.

ここでは, 同一年に 5 時期の衛星画像が得られた 2002 年 4，5，8，10 及び 11 月の ASTER 画像を使用し， この期間における NDVI の時期変動パターンにより埋立 区画内の画素を分類した．本来ならば，現地調査を実施 した 2005 年の衛星画像を用いるべきだが，天候等の問 題により 2005 年では 2 時期分しか撮影されなかったた め, NDVI 時期変動パターンの把握が不可能であった.

画素分類の手順は以下の通りである. まず, 各画像に おいて NDVI を算出し， 5 時期分の NDVI 画像を作成した。 次に, 5 時期分の NDVI 画像を重ねて統合化し, 各時期 の画像をレイヤーとして取り扱うことのできる NDVI 時 期変動画像を作成した. 通常の画像は, 衛星のバンドに 対応したレイヤーを持っているが，ここで作成した画像 では, 各レイヤーはバンドでなく，5 時期の NDVI に対 応した值となっている.この画像のあるピクセルにおい て，5 つのレイヤーの NDVI を抜き出すことで，そのピ クセルにおける NDVI の時期変動を把握することができ る.この NDVI 時期変動画像において，5 時期における NDVI の值の変動パターンにより, 老港処分場内の画素 を 10 の類型に分類した. 分類は，教師なし分類（人為 的な指定に依らず，コンピューターによって自動的に類 型が選定される方法）によって行った. なお，画素の類 型判別には最尤法を用いた. また, NDVI 時期変動画像 および植生分類画像の画素の大きさは, ASTER 画像と同 様, 約 $15 \mathrm{~m} \times 15 \mathrm{~m}$ である.

\section{a) 植生分類結果}

図-8 は, NDVI の時期変動パターンにより，老港処分 場内の画素（水域を除く）を 10 の類型に分類した結果 である. 図-8 の上図は老港処分場内での各類型の分布 図であり，色によって類型の違いが表されている.下の 10 のグラフは各類型の代表的な NDVI 時期変動パターン である. 各グラフ左上にある四角形の色は，分布図にお ける各類型の色を表している.

類型間の NDVI 時期変動パターンの違いとして, (1)全 期間での平均的な NDVI の大きさ, (2)NDVI ピーク時期, (3)4 月から 8 月にかけての NDVI 増加傾向, (4)11 月にお ける NDVI の大きさが確認された. (2)については植生の 最盛期, (3)植生の成長初期, (4)は植生の枯化期を示す と解釈でき, (2)〜 (4)の特徵は植物種による生育または成 長期間の相違を示すものと考えられる. 図-8 の類型

「裸地等」は覆土や廃棄物が露出している箇所であり, 表-6＼cjkstart植物種による生育または成長期間の相違 ${ }^{11), 12}$

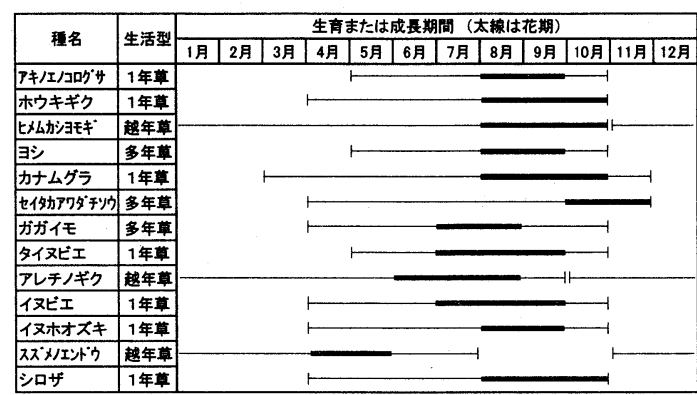

注）一年草または越年草については生育期間を, 多年草については 成長期間を示している.

NDVI は全期間において低くなっている. 他の 9 つの類 型は地表が植生で覆われている箇所と考えられる.

\section{b）植生遷移状況の推定}

図-9 の上図は，老港処分場内のある範囲（図-1 全景 写真において右半分の範囲) の植生分類画像であり, 下 図には対応する範囲内の各区画において埋立が行われた 年を示している. 区画によって埋立年が異なっており， 1 つの区画ではほぼ同時期に埋立が行われている.

ここで, 区画内の植生類型の構成を, 埋立終了からの 経過年数に沿って見ることで, 植生遷移の状況を模擬的 に把握することが可能である. 図-10 は，各区画におけ る類型の構成を埋立終了からの経過時間順に並べたもの である. 優占している類型を埋立終了からの経過時間順 に挙げると, 裸地等 $\rightarrow$ 植生 $1 \rightarrow$ 植生 $4 \rightarrow$ 植生 $7 \rightarrow$ 植生 8 及び 9 であった.

埋立終了後, まず始めに見られる植生類型は植生 1 で ある. 植生 1 の 4 月の NDVI は裸地等と同程度であるこ とから, 植生 1 の芽生え時はほぼ裸地に近い状態である ことがうかがえる. 次に優占する類型は植生 4 である. 植生 1 との違いは, 4 月から 8 月にかけての NDVI 増加傾 向と, 全体的に NDVI が多少高くなっている点である.

植生 1 から植生 4 への遷移では, 植物種は植生 1 に比べ て成長初期が多少遅い種へと変化し, また植物の密集度 が多少高まったと考えられる. 植生 4 から植生 7 への遷 移では, NDVI の時期変動の形状に違いは見られないが, NDVI が全体的に多少高くなっている.この遷移では, 植物種の変化はないが, 植物の密集度がさらに高まった ものと考えられる. 次に優占する植生 8 および 9 は, 4 月の時点で既に NDVI がかなり高く, 年間を通じて植物 の活性が高い状況にあると考えられる. 植生遷移に伴い， NDVI の時期変動パターンには, 春季と最盛期との間の 差が小さくなっていく傾向が見られた.

次に，ある埋立区画内の植生状況の違いを見た. 図一 11 中央の分布図は, 埋立終了後約 2 年経過した区画の 植生分類結果である.ここには主に 5 つの類型が見られ 


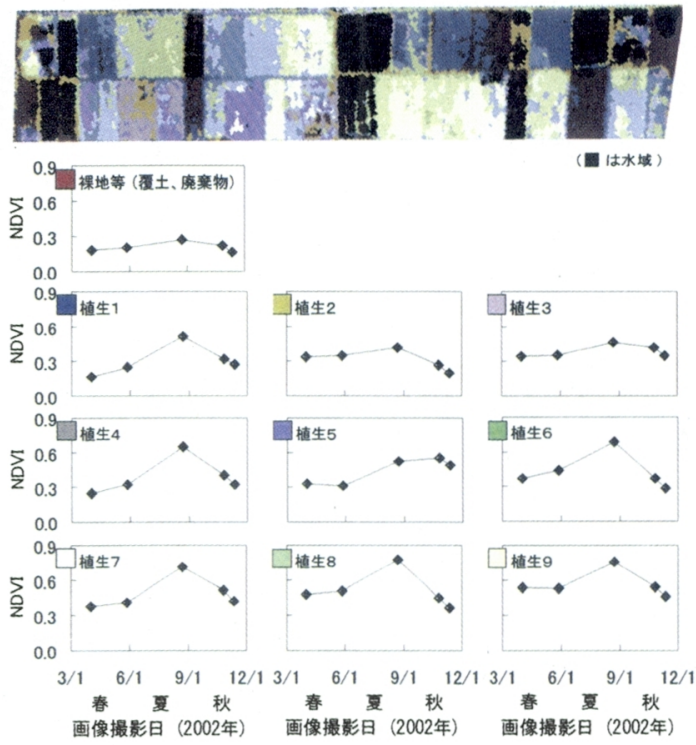

図-8 NDVI 時期変動パターンによる老港処分場内画素分類結果
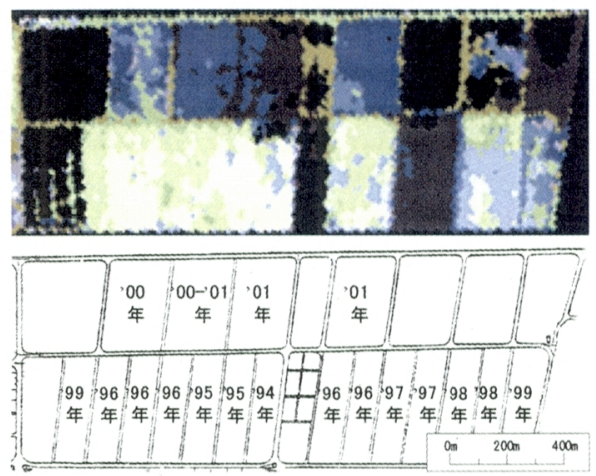

図-9 埋立終了時が判明している区画の植生分類結果

る.植生遷移の段階が最も高いものは植生 6 であり，そ の後高い順に植生 4 , 植生 1 , 裸地等の順である. 植生 3 以遷移の段階が不明な類型である。このように，埋立 終了からの経過時間がほぼ等しいと考えられる範囲に, 遷移段階が異なる類型が分布しており, 特に植生 1 や裸 地等の箇所では，植生遷移が遅延していると考えられる。 植生状況の違いは, 覆土 (材質, 厚さ, 硬度, 含水率) や地形（水溜りの出来など）の影響を少なからず受けて いると考えられるが，植生状況の違いを遷移の遅延と見 なした場合，それは直下にある埋立廃棄物の安定化度の 影響を受けているものと考えられる.

以上の上うな衛星画像解析によって得られる植生分類 と, 現地調査によって得られる植物種や草本層高さを用 いることで, 前節で述べた廃棄物層ガス組成の推定精度 を向上できると考えられる.

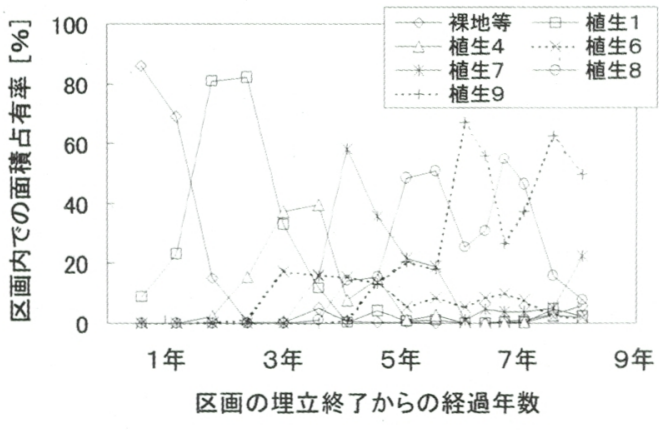

図-10 各類型の埋立区画内での面積占有率

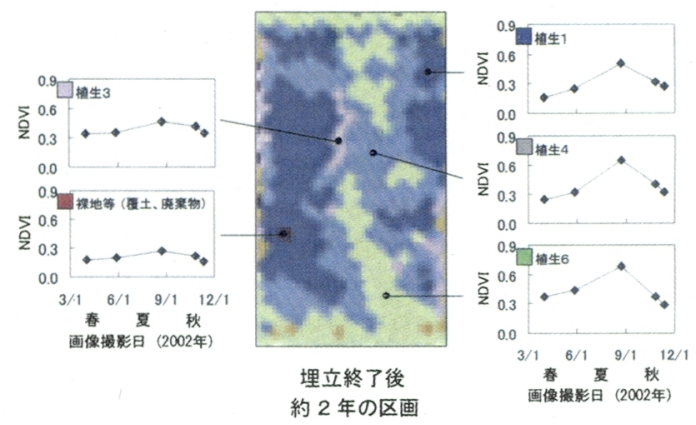

図-11 区画内における植生遷移段階の相違

\section{6. 結論}

本研究では, 広域的かつ定期的に地表の環境情報を取 得できる衛星リモートセンシングに着目し, 大規模廃棄 物最終処分場の安定化モニタリングにおける植生指標 NDVI $の$ 利用可能性について検討を行った. 得られた知 見を以下に示す。

（1）衛星データから算出された NDVI と現地調查で計測 された廃棄物層ガス組成との間にはある程度の相関 が見られた。このことから，衛星りモートセンシン グによって, 最終処分場における廃棄物層ガス組成 の面的分布状況を把握できる可能性が示された.

（2）草本層高さと廃棄物層ガス組成との間にはより高い 相関が見られた．このことから，現地の植生状況を より正確に把握することが可能であれば, 衛星リモ 一トセンシングからの廃棄物層ガス組成の推定精度 は向上することが示唆された。

（3）多時期の衛星画像を用いることで植物種の分類を試 みた。埋立地における植生遷移状況を推定すること ができ，さらに植生遷移が遅延していると考えられ る箇所を検出する手法を示した。

今回の検討は，1 つの処分場を対象としたものである. 最終覆士の種類や施工方法, 気候, 埋立廃棄物の種類な 
どにより, 植生や埋立ガスの発生状況は異なってくると 考えられる. 本稿で述べた NDVI の利用可能性について は, 他の処分場も対象とした検討を重ね, 議論を継続し ていく必要がある.

衛星リモートセンシングによる最終処分場の安定化度 の推定精度を改善していくためには, 現地の植生状況を より詳細に把握可能な手法が必要である. NDVI, 現地植 生情報及び廃棄物層ガスデータとの間の関連性について より詳細な分析を行い, NDVI の高度利用を図る必要が ある. また, 光学センサに加え, 他種のセンサで得られ たデータについても, 安定化モニタリングへの利用可能 性を検討していきたい.

謝辞 : 本研究を進めるにあたり, 中国同済大学の趙由才 教授からは, 研究全般を通じて多大なるご協力を得た.

また, 本研究は, 科学研究費補助金基礎研究「アジアメ ガシティの大規模廃棄物処分場環境モニタリングシステ 么構築のための現地調査」(代表 : 島岡隆行, 研究課題 番号 15404019）の補助を受けて行った成果の一部である. 記して謝意を表する.

\section{参考文献}

1）中華人民共和国国家統計局 : 中国統計年鑑各年版, 中国 統計出版社.

2）石崎俊夫，島岡隆行，中山裕文，小宮哲平，眞鍋和俊： 衛星リモートセンシングによる大規模廃棄物処分場管理 手法に関する研究, 環境システム研究論文集, Vol.32, pp. 311-318, 2004.
3) 石嵪俊夫, 小宮哲平, 中山裕文, 島岡隆行, 久保市浩右, 眞鍋和俊, 大野博之 : アジアメガシティの大規模廃革物 処分場における環境モニタリングのための現地植生調査, 環境システム研究論文集, Vol. 33, pp. 37-45, 2005.

4）石崎俊夫, 島岡隆行, 中山裕文, 小宮哲平 : 埋立廃棄物 の安定化と覆土表層の植生との関連性について, 平成 17 年度土木学会西部支部研究発表会講演概要集, pp. 937-938, 2006.

5）環境庁水質保全局企画課海洋污染・廃棄物対策室：廃棄 物最終処分場安定化監視マニュアル, 全国都市清掃会議, 1989.

6）田中信壽 : 環境安全な廃棄物埋立処分場の建設と管理, 技報堂出版, 2000 .

7） J.Braun-Blanquet（鈴木時夫訳）：植物社会学 I, 朝倉書 店, 1971 .

8）生態学実習贸談会 : 生態学実習書, 朝倉書店, 1967.

9）長野修治, 花嶋正孝, 松藤康司, 柳瀬龍二 : 埋立地の安 定化指標に関する研究，廃棄物処理対策全国協議会第 39 回全国大会講演集，pp. 164-167，1988.

10）リモートセンシング研究会 : 図解リモートセンシング, 日本測量協会, 1992.

11）沼田真, 吉沢長人：新版日本原色雑草図鑑，全国農村教 育協会, 1975 .

12）廣田伸七：ミ二雑草図鑑，全国農村教育協会，1996.

13) T. MURAKAMI, S. OGAWA, N. ISHITSUKA, K. KUMAGAI and G. SAITO : Crop discrimination with multitemporal SPOT/RRV data in the Saga Plains, Japan, International Journal of Remote Sensing, Vol.22, No. 7, pp. 1335-1348, 2001.

\section{APPLICABLITY OF NDVI ON ESTIMATE OF STABILIZATION OF LARGE-SCALE LANDFILL}

\section{Teppei KOMIYA, Toshio ISHZAKI, Hirofumi NAKAYAMA and Takayuki SHIMAOKA}

This study attempted to develop a new method to evaluate landfill stabilization for a large-scale landfill by using NDVI (Normalized Differential Vegetation Index) given from satellite remote sensing data. At Laogang Landfill in Shanghai, which is one of the largest landfills in China, a field survey was carried out to measure the gas composition in landfilled waste layer. Then the relation between the gas composition and NDVI calculated from ASTER satellite data was examined. Results indicated that there were negative correlation between NDVI and the proportion of landfill gas composition such as $\mathrm{CH}_{4}$ and $\mathrm{CO}_{2}$. It was shown that the distribution of gas composition in a landfill could be estimated by using NDVI. 